\title{
FAKTOR-FAKTOR YANG MEMPENGARUHI WISATAWAN DALAM MELAKUKAN PEMESANAN AKOMODASI MELALUI ONLINE TRAVEL AGENTS DI KAWASAN WISATA UBUD
}

\author{
Putu Agus Wikanatha Sagita ${ }^{1}$, I Made Kusuma Negara ${ }^{2}$ \\ ${ }^{1}$ Email: aguswika@unud.ac.id \\ Program Studi Industri Perjalanan Wisata, Fakultas Pariwisata, Universitas Udayana \\ ${ }^{2}$ Email: kusum.negara@unud.ac.id \\ Program Studi Industri Perjalanan Wisata, Fakultas Pariwisata, Universitas Udayana
}

\begin{abstract}
This study aims to (1) Identifying the characteristics of tourists who have booked accommodation through Online Travel Agents in Ubud Tourist Area, (2) Identifying factors that encourage tourists to book accommodation through Online Travel Agents in Ubud Tourist Area , (3) Identifying what is the most dominant factor encouraging tourists to book accommodation through Online Travel Agents in Ubud Tourist Area. Data in this study was conducted with observation, interview, questionnaire and literature study techniques. Data analysis technique used is quantitative descriptive analysis and factor analysis. The characteristics of respondents in this study based on age are dominated by tourists with an age range of 21-30 years, which is $53.3 \%$ or with a total of 96 people. Based on the length of stay dominated by tourists who stay 1-4 days, which is $57.8 \%$ or with a total of 104 people. The Online Travel Agent most used by respondents is booking.com, which is $48.9 \%$ or used by 88 people. Based on the analysis of factors produced four factors that influence tourists who book accommodations through online travel agents in the Ubud Tourist Area, namely 1) Efficiency factors: (a) Saving Energy, (b) Saving Time, (c) Shopping every time. 2) Preference Factors: (a) Economical, (b) Product Use, (c) Price Competition, and (d) References. 3) Psychological Factors: (a) Learning, (b) Perception, (c) Motivation, and (d) Facilities and Infrastructure. 4) Trust Factors: (a) Trust in the Internet, (b) Trust in Applications, and (c) Security Perceptions.
\end{abstract}

Abstrak: Penelitian ini bertujuan untuk (1) Mengidentifikasi karakteristik wisatawan yang melakukan pemesanan akomodasi melalui Online Travel Agents di Kawasan Wisata Ubud, (2) Mengidentifikasi Faktor - faktor apakah yang mendorong wisatawan dalam melakukan pemesanan akomodasi melalui Online Travel Agents di Kawasan Wisata Ubud, (3) Mengidentifikasi Faktor apakah yang paling dominan mendorong wisatawan dalam melakukan pemesanan akomodasi melalui Online Travel Agents di Kawasan Wisata Ubud. Pengumpulan data dalam penelitian ini dilakukan dengan teknik observasi, wawancara, kuesioner dan studi kepustakaan. Teknik analisis data yang dipergunakan adalah analisis deskriptif kuantitatif serta analisis faktor. Karakteristik responden dalam penelitian ini berdasarkan umur didominasi oleh wisatawan dengan rentang umur 21-30 tahun, yaitu 53,3\% atau berjumlah 96 orang. Berdasarkan lama tinggal didominasi oleh wisatawan yang tinggal 1-4 hari, yaitu sebesar 57,8\% atau berjumlah 104 orang. Adapun Online Travel Agent yang paling banyak digunakan oleh responden adalah booking.com, yaitu sebesar 48,9\% atau digunakan oleh 88 orang. Berdasarkan analisis faktor dihasilkan empat faktor yang mempengaruhi wisatawan yang melakukan pemesanan akomodasi melalui online travel agents, yaitu 1)Faktor efisiensi: (a)Menghemat Tenaga , (b)Menghemat Waktu, (c)Berbelanja setiap waktu. 2)Faktor Preferensi: (a)Hemat, (b)Penggunaan Produk, (c)Persaingan Harga, (d) Referensi. 3)Faktor Psikologis: (a)Pembelajaran, (b)Persepsi, (c)Motivasi, (d)Sarana dan Prasarana. 4)Faktor Kepercayaan: (a)Kepercayaan pada Internet,(b) Kepercayaan pada Aplikasi, (c)Persepsi Keamanan.

Keywords: digital tourism, online travel agents, tourist accommodation. 


\section{PENDAHULUAN}

Bali yang terkenal dengan keindahan alam dan keunikan budayanya telah menjadi salah satu destinasi pariwisata favorit dunia. Pertumbuhan kunjungan wisatawan yang terjadi dari tahun ke tahun merupakan stimulus bagi pesatnya perkembangan industri hospitalitas yang menyediakan berbagai produk wisata. Perkembangan industri pariwisata di Bali tidak dapat terlepas dari geliat teknologi informasi yang dapat dijadikan sarana pemasaran yang berbiaya rendah (low cost) namun memiliki dampak yang besar (high impact) dalam rangka meraih pasar potensial.

Fenomena perkembangan pariwisata Bali berbasis digital kian nyata terlihat karena saat ini dapat dengan mudah merencanakan perjalanannya termasuk memesan segala produk wisata yang dibutuhkan hanya dengan mengakses mengakses website ataupun aplikasi yang terdapat pada perangkat ponsel pintar. Hal ini sangat dimungkinkan khusunya sejak kemunculan Online Travel Agents yang dapat diartikan sebagai usaha agen perjalanan secara online, yang fokus menangani penjualan berbagai produk pariwisata dari berbagai usaha pariwisata yang menjadi mitra kerjanya. Usaha pariwisata yang bekerja sama dengan online travel agents mulai dari penjualan jasa penerbangan, usaha akomodasi, dan usaha pariwisata lainnya (Astuti, 2015). Berdasarkan hasil survey yang dilakukan oleh www.ebizmba.com pada tahun 2017 tidak kurang dari 5 Online Travel Agent telah masuk dalam top 15 most popular travel websites, antara lain : booking.com, expedia, priceline.com, hotels.com, dan Travelocity yang mana keberadaannya dapat membuka peluang bagi industri pariwisata lokal untuk dapat bersaing meraih pasar sekalipun dengan dukungan sumber daya yang terbatas.

Demi menghadapi persaingan saat ini, para pengelola akomodasi di Kawasan Wisata Ubud telah menggunakan teknologi informasi khususnya internet untuk menarik wisatawan yang ingin menginap. Salah satu cara yang dapat dilakukan adalah bekerjasama dengan Online Travel Agents (OTA). Sesuai dengan namanya, Online Travel Agents (OTA) memfokuskan kegiatan usaha pemasaran secara online baik melalui media sosial, website hingga aplikasi pada smartphone yang telah menjadi gaya hidup yang secara tidak langsung mempengaruhi bagaimana wisatawan mengelola perjalanannya saat ini.

Peran Online travel agents sebagai saluran distribusi produk pariwisata secara digital turut menimbulkan kekhawatiran bahwa Biro Perjalanan Wisata konvensional akan ditinggalkan dan tidak dapat meraih pasar. Hal tersebut sejalan dengan pernyataan Mentri Pariwisata Arief Yahya pada Rapat Kerja Nasional (Rakernas) II Association of the Indonesian Tour \& Travel Agencies (ASITA) pada tanggal 10 November 2017 yang mengatakan bahwa "Mereka, para online travel agent ini, melakukan sharing ekonomi, mengoptimalkan kapasitas, menjual yang kosong dengan harga murah dan mencari return dari cross selling. Ini semua bisa berjalan dengan cara digital. Bila travel agent masih berharap pada transaksi dengan pertemuan, pasti akan bernasib sama seperti wartel yang mati dengan munculnya seluler" (www.cnnindonesia.com, 2017). Berdasarkan pernyataan tersebut dapat dilihat bahwa tidak ada jalan lain bagi Biro Perjalanan Wisata konvensional untuk bertahan selain turut melakukan digitalisasi sehingga relevan dengan dengan kebutuhan pasar akan akses informasi serta transaksi yang cepat khususnya bagi kaum millennial.

Berdasarkan fenemona tersebut, penelitian berjudul "Faktor-Faktor yang Mempengaruhi Wisatawan dalam Melakukan Pemesanan Akomodasi Melalui Online travel agents di Kawasan Wisata Ubud" menjadi menarik untuk diteliti. Hasil dari penelitian ini diharapkan dapat menjadi bahan pertimbangan bagi pemerintah sebagai pembuat kebijakan dalam pengembangan pariwisata khususnya di Kawasan Wisata Ubud. Selain itu, hasil penelitian ini diharapkan dapat menjadi masukan bagi Biro Perjalanan Wisata konvensional, sehingga dapat mengambil langkah strategis dalam melakukan pemasaran berbasis digital.

\section{METODE PENELITIAN}

Penelitian dilakukan di Kawasan Wisata Ubud, tepatnya adalah pada daya tarik wisata 
Monkey Forest, Pasar Ubud dan Puri Ubud. Dipilihnya daya tarik wisata Monkey Forest, Pasar Ubud dan Puri Ubud sebagai tempat penyebaran kuisioner didasakan pada hasil observasi awal, bahwa wisatawan mancanegara banyak melakukan kegiatan wisatanya di tiga lokasi tersebut, sehingga memudahkan peneliti untuk menyebarkan kuisioner.

Dalam penelitian ini, terdapat enam indikator, antara lain : 1. Variabel Psikologis yang terdiri dari indikator (X1) Persepsi, (X2) Motivasi, (X3) Pembelajaran; 2. Variabel Situasional yang terdiri dari indikator (X4) Sarana dan prasarana, (X5) Penggunaan produk, (X6) Kondisi saat pembelian; 3. Variabel Sosial, yang terdiri dari indikator (X7) Keluarga, (X8) Kelompok refrensi, (X9) Budaya; 4. Variabel Harga yang terdiri dari indikator (X10) Hemat, (X11) Persaingan harga; 5. Variabel Kepercayaan yang terditi dari indikator (X12) Persepsi Keamanan, (X13) Kepercayaan pada internet, (X14) Kepercayaan pada Online travel agents; 6. Variabel Kenyamanan yang terdiri dari indikator (X15) Menghemat waktu, (X16) Menghemat tenaga, (X17) Berbelanja setiap saat.

Adapun pengumpulan data dalam penelitian ini dilakukan dengan observasi langsung melalui pengamatan dan pencatatan fenomena-fenomena yang tampak di Kawasan Wisata Ubud, penyebaran kuesioner dengan menggunakan skala likert, wawancara untuk mendapat informasi yang diperlukan dengan menggunakan alat pedoman wawancara (interview guide), dan studi kepustakaan yang dilakukan dengan cara mengumpulkan data sekunder yang dijadikan landasan teoritis serta sebagai pedoman untuk melakukan penelitian.

Sampel dalam penelitian ini ditentukan sebanyak 180 orang wisatawan. Pengambilan sampel dilakukan dengan metode purposive, dimana responden penelitian adalah wisatawan yang pernah melakukan pemesanan akomodasi di Kawasan Wisata Ubud melalui Online Travel Agents.

\section{HASIL DAN PEMBAHASAN}

Berdasarkan karakteristiknya seluruh responden dalam penelitian merupakan wisatawan mancanegara yang terdiri dari $45 \%$ laki-laki atau berjumlah 81 orang dan $55 \%$ perempuan atau berjumlah 99 orang. Persentase wisatawan yang belum menikah sebesar $67,8 \%$ atau berjumlah 122 orang. Sedangkan persentase wisatawan yang sudah menikah sebesar $32,2 \%$ atau berjumlah 58 orang. Berdasarkan rentang umur, jumlah wisatawan tertinggi berada pada rentang umur 21-30 tahun, yaitu 53,3\% atau berjumlah 96 orang. Sedangkan persentase yang paling rendah adalah wisatawan yang berumur lebih dari 40 tahun, yaitu 9,4\% atau berjumlah 17 orang. Wisatawan yang pertama kali berkunjung ke Ubud dengan presentase tertinggi yaitu sebesar $71,7 \%$ atau berjumlah 129 orang. Sedangka persentase terendah adalah wisatawan yang telah berkunjung ke Ubud $2-5$ kali sebesar 26,7\% atau berjumlah 48 orang. Berdasarkan lama tinggal didominasi oleh wisatawan yang tinggal 1-4 hari, yaitu sebesar $57,8 \%$ atau berjumlah 104 orang. Selanjtnya diikuti dengan lama tinggal 1 minggu sebesar $22,8 \%$ atau sebanyak 41 orang. Adapun Online Travel Agent yang paling banyak digunakan adalah booking.com, yaitu sebesar $48,9 \%$ atau berjumlah 88 orang. Selanjutnya diikuti oleh Agoda dengan presentase sebesar $15 \%$ atau berjumlah 27 orang. Jenis akomodasi yang paling banyak dipesan melalui Online Travel Agents adalah akomodasi berjenis villa, yaitu sebesar 32,8\% atau berjumlah 59 unit. Kemudian, jenis akomodasi yang dipesan terbanyak kedua adalah homestay yaitu sebesar $11,7 \%$ atau berjumlah 21 unit. Dari data karakteristik wisatawan dapat terlihat bahwa jenis akomodasi homestay yang mayoritas dikelola oleh masyarakat lokal di Ubud dapat dipesan melalui Online Travel Agents booking.com.

Analisis faktor dalam penelitian ini dilakukan dengan beberapa tahapan. Pada tahap pertama dilkukan indentifiksi 16 inidikator penentu keputuasan pembelian yang kemudian diiuji besarnya hubungan antar indikator. Pada Uji Bartlett's Bartlett Test of Sphericity didapatkan nilai 1221.102 dengan signifikansi 0,000 . Hasil ini menunjukkan bahwa antara indikator terjadi korelasi dan dengan demikian peluang untuk terjadinya kesalahan pada variabel yang tidak independen sebesar $0 \%$. Pada uji Uji Kaiser Meyer Olkin (KMO) diperoleh nilai sebesar 0,795 , yang berarti angka ini menunjukkan syarat kecukupan yang sudah 
melebihi 0,5 dan memenuhi kriteria untuk dilakukan proses ke langsung selanjutnya. Pada uji Measure of Sampling Adequacy (MSA) dapat diketahui bahwa dari ke 16 indikator, ada satu indikator yang memiliki nilai kurang dari 0,5 yaitu indikator keluarga (X7) yang memiliki nilai 0,387 , sehingga indikator tersebut tidak dapat digunakan pada analisis berikutnya. Maka ke 15 indikator digunakan pada analisis selanjutnya karena memenuhi persyaratan nilai standar dari MSA > 0,5.

Selanjutnya dilakukan penentuan jumlah faktor. Pada tahap ini terbentuk empat faktor dari 15 indikator yang mempengaruhi keputusan wiatawan dalam melakukan pemesanan akomodasi melalui Online travel agents di Kawasan Wisata Ubud. Keempat faktor tersebut memiliki eigenvalue > 1, yaitu 5.201, 2.037, 1.426 , dan 1.075 dimana faktor yang terbentuk menjelaskan $64.926 \%$ total varian variabel yang mempengaruhi keputusan wiatawan dalam melakukan pemesanan akomodasi melalui Online travel agents di Kawasan Wisata Ubud.

Selanjutnya rotasi faktor dilakukan dengan rotasi varimax. Berdasarkan hasil analisis rotasi maka dapat dipaparkan bahwa dari ke 15 indikator yang telah dirotasi, terdapat 14 indikator yang memenuhi syarat atau kriteria dan terdapat satu indikator yang tidak memenuhi kriteria dikarenakan loading factor yang tidak mencapai 0,5 . Indikator yang dimaksud adalah kondisi pembelian (X6). Selanjutnya dengan metode Principal Componen Analisis (PCA) maka indikator yang tersisa tersebar dalam empat faktor yang merupakan faktor-faktor yang mempengaruhi keputusan wiatawan dalam melakukan pemesanan akomodasi melalui Online travel agents di Kawasan Wisata Ubud. Adapun komponen indikator yang masuk ke dalam faktor yang pertama terdiri dari Menghemat Tenaga (X16), Menghemat Waktu (X15), Berbelanja setiap waktu (X17). Indikator yang lainnya masuk ke faktor yang kedua terdiri dari Hemat (X10), Penggunaan Produk (X5), Persaingan Harga (X11), Refrensi (X8). Selanjutnya indikator yang masuk ke dalam faktor yang ketiga yaitu Pembelajaran (X3), Persepsi (X1), Motivasi (X2), Sarana dan Prasarana (X4). Indikator selanjutnya masuk ke dalam faktor yang keempat, yaitu Kepercayaan pada Internet (X13), Kepercayaan pada Aplikasi
(X14), Persepsi Keamanan (X12). Pada tahap selanjutnya dilakuakan interpretasi faktor. Pada tahapan ini faktor yang merupakan gabungan dari suatu indikator harus diberi nama. Pemberian nama harus mengacu pada indikator - indikator yang membentuk faktor yang bersangkutan atau berdasarkan pada indikator yang mempunyai loading factor tertinggi Adapun hasil dari dapat dipaparkan pada Tabel 1 berikut ini.

Tabel 1.

Faktor-Faktor yang Mempengaruhi Wisatawan

Dalam Melakukan Pemesanan Akomodasi Melalui Online Travel Agents di Kawasan Wisata Ubud

\begin{tabular}{|c|c|c|c|c|}
\hline $\begin{array}{l}\text { Nama } \\
\text { Faktor }\end{array}$ & $\begin{array}{c}\text { Nama } \\
\text { Indikator }\end{array}$ & $\begin{array}{l}\text { Eigen } \\
\text { Value }\end{array}$ & $\begin{array}{c}\text { Loading } \\
\text { Factor }\end{array}$ & $\begin{array}{r}\text { Percent of } \\
\text { Variance }\end{array}$ \\
\hline \multirow{3}{*}{$\begin{array}{c}\text { Faktor } \\
\text { Efisiensi }\end{array}$} & $\begin{array}{l}\text { Menghem } \\
\text { at Tenaga } \\
\text { (X16) }\end{array}$ & \multirow{3}{*}{5.201} & 0.905 & \multirow{3}{*}{34.672} \\
\hline & $\begin{array}{l}\text { Menghem } \\
\text { at Waktu } \\
\text { (X15) }\end{array}$ & & 0.903 & \\
\hline & $\begin{array}{l}\text { Berbelanj } \\
\text { a setiap } \\
\text { waktu } \\
\text { (X17) }\end{array}$ & & 0.604 & \\
\hline \multirow{4}{*}{$\begin{array}{c}\text { Faktor } \\
\text { Preferensi }\end{array}$} & $\begin{array}{l}\text { Hemat } \\
\text { (X10) }\end{array}$ & \multirow{4}{*}{2.037} & 0.767 & \multirow{4}{*}{13.579} \\
\hline & $\begin{array}{l}\text { Pengguna } \\
\text { an Produk } \\
\text { (X5) }\end{array}$ & & 0.685 & \\
\hline & $\begin{array}{l}\text { Persainga } \\
\mathrm{n} \text { Harga } \\
(\mathrm{X} 11)\end{array}$ & & 0.682 & \\
\hline & $\begin{array}{l}\text { Referensi } \\
(\mathrm{X} 8)\end{array}$ & & 0.599 & \\
\hline \multirow{3}{*}{$\begin{array}{c}\text { Faktor } \\
\text { Psikologis }\end{array}$} & $\begin{array}{l}\text { Pembelaja } \\
\text { ran (X3) }\end{array}$ & \multirow{3}{*}{1.426} & 0.838 & \multirow{3}{*}{9.505} \\
\hline & $\begin{array}{l}\text { Persepsi } \\
(\mathrm{X} 1)\end{array}$ & & 0.729 & \\
\hline & Motivasi & & 0.669 & \\
\hline
\end{tabular}




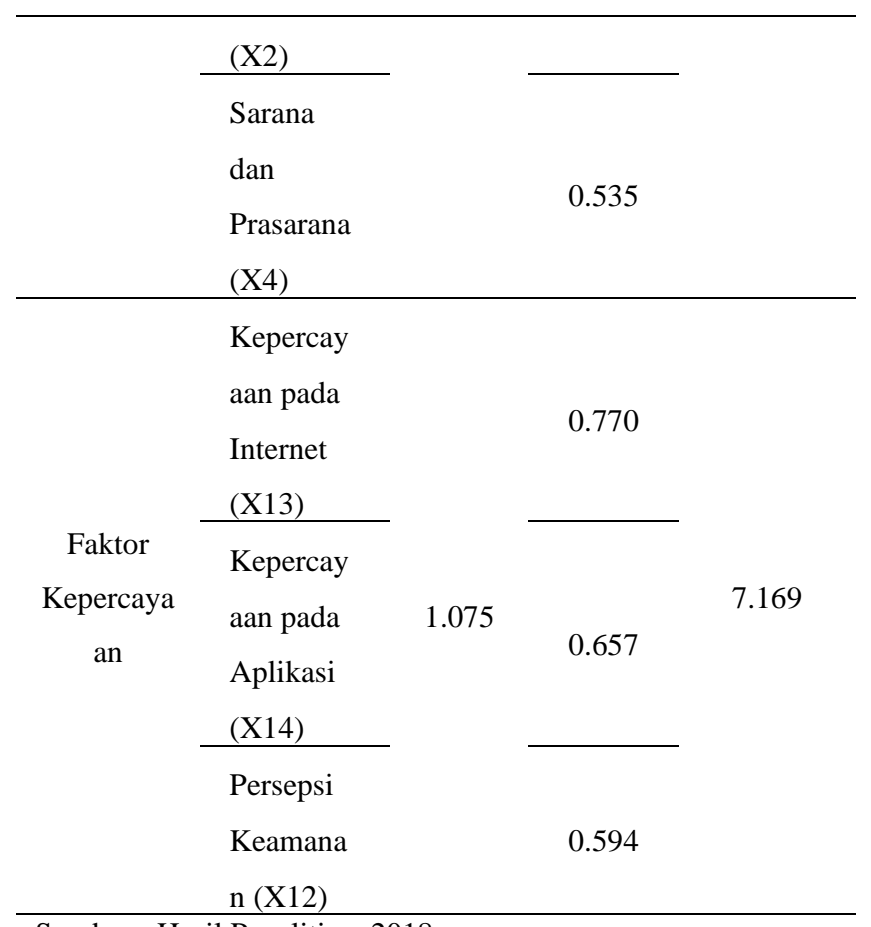

Sumber : Hasil Penelitian, 2018

Berdasarkan Tabel 1, di atas, dapat ditemukan empat faktor terdiri atas 14 indikator yang memiliki pengelompokan baru. Faktorfaktor baru yang telah terbentuk diberi nama sesuai dengan indikator yang telah dikelompokan. Hal ini dapat dapat diuraikan sebagai berikut:

a. Faktor 1

Faktor pertama diberi nama Faktor Efisiensi yang memiliki nilai eigenvalue sebesar 5.201 . Adapun Faktor Efisiensi terdiri dari Menghemat Tenaga (X16), Menghemat Waktu (X15), dan Berbelanja setiap waktu (X17).

b. Faktor 2

Faktor kedua diberi nama Faktor Preferensi yang memiliki nilai eigenvalue sebesar 2.037. Adapun Faktor Preferensi terdiri dari indikator Hemat (X10), Penggunaan Produk (X5), Persaingan Harga (X11), dan Refrensi (X8).

c. Faktor 3

Faktor yang ketiga diberi nama Faktor Psikologis yang memiliki nilai eigenvalue sebesar 1.426. Adapun Faktor Psikologis terdiri dari indikator Pembelajaran (X3),
Persepsi (X1), Motivasi (X2), dan Sarana dan Prasarana (X4).

\section{d. Faktor 4}

Faktor yang keempat diberi nama Faktor Kepercayaan yang memiliki nilai eigenvalue sebesar 1.075. Adapun faktor kualitas produk terdiri dari indikator Kepercayaan pada Internet (X13), Kepercayaan pada Aplikasi (X14), Persepsi Keamanan (X12).

Faktor yang Dominan Mempengaruhi Keputusan Wisatawan Dalam Melakukan Pemesanan Akomodasi Melalui Online Travel Agents di Kawasan Wisata Ubud.

Faktor yang dominan dalam mempengaruhi keputusan pembelian dapat dilihat dari nilai eigenvalue tertinggi yaitu Faktor Efisiensi dengan eigenvalue sebesar 5,201 dan memiliki percent of variance sebesar $34,672 \%$.

Hasil tersebut didukung oleh penelitian Devaraj (2003) yang menjelaskan bahwa keputusan membeli secara online dipengaruhi Efisiensi untuk pencarian: waktu cepat, mudah dalam penggunaan dan usaha pencarian mudah. Kemudahan dalam mencari informasi tergantung dari layout halaman website. Jika layout cukup jelas, waktu yang digunakan untuk searching dapat dipersingkat. Usaha untuk searching lebih mudah. Sehingga efisiensi meningkat.

Faktor Efisiensi dalam penelitian ini terdiri dari tiga indikator yang mempengaruhi keputusan wisatawan dalam melakukan pemesanan akomodasi melalui online travel agents di Kawasan Wisata Ubud. Adapun tiga indikator yang dimaksud adalah menghemat tenaga sebagai indikator pertama, yang menyangkut efisiensi yang dirasakan oleh wisatawan saat melakukan pemesanan akomodasi melalui online travel agent yaitu wisatawan tidak perlu bersusah payah menghubungi ataupun datang langsung ke kantor agen perjalanan untuk memesan akomodasi. Hal tersebut didukung hasil wawancara dengan seorang wisatawan yang menyatakan "lebih mudah untuk memesan liburan sendiri melalui booking. com dll setelah meninjau hotel di tripadvisor" (Bronson, 2018). Berdasarkan pernyataan tersebut dapat diketahui bahwa selain menggunakan pemesananan 
akomodasi melalui Online Travel Agents, peranan situs perjalanan yang menyediakan review pembanding terkait akomodasi juga penting bagi wisatawan untuk memutuskan melakukan pemesanan. Park \& Lee (2009) menyatakan bahwa review online dapat memfasilitasi konsumen didalam proses membuat keputusan pembelian. Salah satu alasan utama bagi para konsumen dalam mencari informasi hotel secara online adalah kegunaan dari online review yang menyajikan informasi yang tidak membingungkan sesuai dengan keinginan pelanggan.

Indikator kedua yaitu menghemat waktu, konsumen yang sibuk akan menganggap mengunjungi kantor agen perjalanan sebagai hal yang tidak menguntungkan. Layanan pemesanan produk wisata secara elektronik menawarkan konsumen yang sibuk kesempatan untuk menghemat waktu (Srinivasan dan Ratchford, 1991). Hal tersebut didukung hasil wawancara dengan seorang wisatawan yang menyatakan Pernyataan "saya merasa sangat mudah melakukan navigasi, melihat gambar, ulasan, harga komparatif dan proses pemesanan yang mudah (user friendly)" (Raine, 2018). Berdasarkan pernyataan tersebut dapat diketahui bahwa saat ini dengan keberadaan Online Travel Agents yang dapat diakses melalui website ataupun aplikasi yang ter-install pada smarthphone wisatawan dapat membadingkan akomodasi yang diinginkan dengan cepat dan mudah. Hal tersebut juga didukung dengan tampilan yang interaktif, sehingga wisatawan yang baru pertama kali mengunjungi suatu destinasi sekalipun dapat mengetahui dengan jelas kekurangan dan kelebihan dari akomodasi yang akan dipesan dalam waktu singkat.

Selanjutnya, indikator ketiga adalah Berbelanja setiap waktu, yang menyangkut kemudahan dirasakan oleh wisatawan dari aplikasi yang umumnya telah ter-install pada smarthphone mereka. Hal tersebut memungkinkan wisatawan dapat melakukan pemesanan akomodasi dimana saja dan kapan saja. Hal ini dapat dikatakan sebagai potensi yang menjanjikan sekaligus menjadi tantangan bagi pihak Online Travel Agents yang bersaing dalam merebut pasar tersebut. Selain dituntut untuk menyediakan aplikasi yang interaktif dan sistem booking yang handal, menjadi penting bagi wisatawan untuk mendapatkan informasi yang lengkap serta ulasan yang apa adanya mengenai produk akomodasi yang akan dipesan sehingga value yang diterima dari akomodasi tersebut dapat memenuhi harapan wisatawan.

Dalam hal ini, pemilik homestay yang dikelola oleh masyarakat lokal memiliki peluang dalam upaya pemasaran dengan memanfaatkan sistem booking yang disediakan Online Travel Agents. Hal ini didukung hasil wawancara dengan seorang salah satu pemilik homestay yang menyatakan "Dari booking.com kita biasanya pakai sistem lewat website. Bisa dipakai block kamar, kita juga bisa cek review tamu dan berapa komisi untuk mereka. Sekarang tinggal gimana kita jaga supaya dapat ranking yang bagus" (Risyamuka, 2018). Berdasarkan pernyataan tersebut dapat diketahui bahwa saat ini pemilik homestay di Ubud telah melakukan kerjasama dengan Online Travel Agents dalam hal ini adlaah situs booking.com. Bentuk kerjasama dilakukan dengen sistem bagi komisi, dimana pihak Online Travel Agents berhak atas komisi dari hasil penyewaan kamar. Sebagai timbal balik, pemilik homestay mendapatkan akses untuk menggunakan sistem booking melalui website. Adapun fitur-fitur yang dapat digunakan pada sistem, antara lain: property info, promotions, statistics, finance, website content, rates \& availability. Berbagai fitur yang disediakan dapat digunakan untuk menampilkan profil mengenai akomodasi yang ditawarkan, mengelola ketersediaan kamar, memeriksa keuntungan dari penjualan kamar sekaligus besar komisi yang harus dibayarkan kepada Online Travel Agents, hingga membuat promosi berupa potongan harga pada kondisi tertentu seperti low season.

\section{SIMPULAN DAN SARAN}

\section{Simpulan}

1. Faktor-Faktor yang mempengaruhi keputusan wiatawan dalam melakukan pemesanan akomodasi melalui online travel agents di Kawasan Wisata Ubud, yaitu:

a. Faktor Efisiensi, terdiri dari indikator Menghemat Tenaga, Menghemat Waktu, dan Berbelanja setiap waktu.

b. Faktor Preferensi, terdiri dari indikator Hemat, Penggunaan Produk, Persaingan Harga, dan Referensi. 
c. Faktor Psikologis, terdiri dari indikator Pembelajaran, Persepsi, Motivasi, dan Sarana dan Prasarana.

d. Faktor Kepercayaan, terdiri dari indikator Kepercayaan pada Internet, Kepercayaan pada Aplikasi, dan Persepsi Keamanan.

2. Faktor yang dominan mempengaruhi keputusan wiatawan dalam melakukan pemesanan akomodasi melalui online travel agents di Kawasan Wisata Ubud adalah faktor efisiensi. Hal ini terkait dengan perkembangan teknologi informasi yang pesat, dimana orang ataupun wisatwan cenderung memilih cara yang paling cepat, mudah dan tidak menghabiskan banyak tenaga untuk memenuhi kebutuhan perjalanannya. Melalui aplikasi online travel agent yang ter-install pada smartphone hal tersebut sangat mungkin untuk dilakukan. Selain itu, banyaknya promosi menarik yang ditawarkan pada aplikasi tersebut turut mempengaruhi wisatwan dalam memesan akomodasi melalui online travel agents.

\section{Saran}

1. Sebaiknya pelayanan maupun tampilan nyata akomodasi tidak jauh berbeda dengan gambar ataupun penawaran yang ditampilkan pada aplikasi.

2. Online travel agents sebaiknya menampilkan lebih banyak ulasan dari pelanggan yang telah menginap pada akomodasi yang ditawarkan sehingga wisatawan dapat melihat kelebihan dan kekurangan dari akomodasi yang ingin dipesan .

3. Online travel agents hendaknya memberikan respon yang lebih cepat ketika wisatawan bertanya ataupun menyampaikan keluhan.

4. Online travel agents diharapkan selalu memasarkan produk wisata sesuai dengan kesepakatan harga online yang telah diatur pada kontrak kerjasama. Sehingga dapat mewujudkan persaingan yang sehat dengan Biro Perjalan Wisata konvensional. 


\section{Kepustakaan}

Astuti, Luh Astuti. 2015. "Persepsi Penegelolaan Villa di Kecamatan Kuta Utara Terhadap Penggunaan Online Travel Agents sebagai Media Promosi dan Penjualan". (Tesis) Magister Pariwisata Universitas Udayana.

Devaraj, Fan, and Kohli, (2003). E-Loyalty elusive ideal or competitive edge?. Communication of the ACM 46, 9 (Sept.2003), 184-191.

Park, C., and Lee, T.M., 2009, Antecedents of online reviews' usage and purchaseinfluence: an empirical comparison of US and Korean Consumers,Journal ofInteractive Marketing, vol 23 no 4, 332-340.

Srinivasan, N. \& B. Ratchford (1991). An empirical test of an external search for auto-mobiles.Journal of Consumer Research,18 (4): 233-242.

https://www.cnnindonesia.com/gayahidup/20171112221647-307-

255138/menpar-ingatkan-travel-agentberalih-ke-digital-tourism, diakses tanggal 28 Januari 2018.

http://www.ebizmba.com/articles/travelwebsites, diakses tanggal 28 Januari 2018. 